Agnieszka Więckiewicz

Wydział Polonistyki, Uniwersytet Warszawski

\title{
(Auto)analityczny opis przypadku. Wspomnienia Izydora Sadgera o Zygmuncie Freudzie ${ }^{1}$
}

Dla pierwszych psychoanalityków zarówno pisanie biografii czy autobiografii, jak i prowadzenie dzienników oraz notatników było praktyką codzienną. Dzięki badaniom Didera Anzieu [1959], Jacques'a Le Ridera [2000], Petera L. Rudnytsky'ego [2002] czy Ilse Grubrich-Simitis [1997] nie można pominąć ogromnej roli intymistyki w rozwoju psychoanalizy. W artykule przyglądam się biografii Zygmunta Freuda autorstwa Izydora Izaaka Sadgera, jednego z pierwszych uczniów twórcy psychoanalizy. Na przykładzie Sigmund Freud. Persönliche Erinnerungen [Sadger 2005] postaram się pokazać, jak biografia może przerodzić się w psychoanalityczny opis przypadku, a zarazem stanowić dzieło autobiograficzne oparte na autoanalizie. W pierwszej części tekstu proponuję przyjrzeć się związkom psychoanalizy z intymistyką jako praktyką codziennego zapisu służącą przede wszystkim samoobserwacji. Następnie przybliżam postać zapomnianego freudysty i omawiam biografię jego autorstwa w kontekście relacji z Freudem oraz zajmowanej pozycji

1 Artykuł został sfinansowany w ramach „Diamentowego Grantu” przyznanego przez Ministerstwo Nauki i Szkolnictwa Wyższego, nr 0046/DIA/2018/47. 
w Wiedeńskim Towarzystwie Psychoanalitycznym. W ostatniej części podejmuję analizę biografii Freuda jako dzieła spajającego i mieszającego odrębne gatunki literackie.

\section{Między biografią a opisem przypadku, autobiografią a autoanalizą}

Jak zauważa Lionel Trilling, autor wstępu do Life and Work of Sigmund Freud Ernesta Jonesa [1962: 11], Freud nigdy nie chciał być bohaterem biografii. Mimo to wielu z jego uczniów podjęło się spisania historii życia twórcy psychoanalizy. Jak zauważył Anzieu, większość z tych dzieł przerodziła się w hagiografie, które uwznioślały postać autora Objaśniania marzeń sennych, a tym samym tworzyły nierzeczywisty obraz narodzin i rozwoju freudyzmu [Anzieu 1959: 13]. Wielu spośród psychoanalityków pozostawiło po sobie wspomnienia i autobiografie, których głównym tematem była współpraca z Freudem. Należeli do nich m.in. Abraham Arden Brill, Roy Grinker, Theodor Reik, Max Graf [Ruitenbeek, red. 1973], Wilhelm Stekel [1950], Ernest Jones [1959], Bruno Goetz [1969], Edoardo Weiss [1970], Max Schur [1972], Helena Deutsch [1973] oraz Fritz Wittels [1995]. Pierwszą książkę poświęconą życiu Freuda napisał Wittels $[1924]^{2}$. Jego praca Sigmund Freud. Der Mann, die Lehre, die Schule została wydana 1924 roku i, podobnie jak późniejszy tekst Sigmund Freud. Persönliche Erinnerungen autorstwa Sadgera, nie wpisywała się w nurt pochwalnych biografii poświęconych autorowi Totemu $i$ tabu. Jej publikacja doprowadziła do konfliktu między autorem a Freudem, który uznał tekst Wittelsa za plotkarski i fałszywy [Rider 2000: 152-153] ${ }^{3}$. W kolejnych latach Wittels napisał jeszcze jedną biografię Freuda

Wittelsa do Środowego Towarzystwa Psychologicznego wprowadził w 1906 roku Sadger. Do Wiedeńskiego Towarzystwa Psychoanalitycznego Wittels należał w latach 1906-1910, a następnie od 1927 do 1936 [Mühlleitner 1992: 282-283, 369-371].

3 Konflikt między Freudem a Wittelsem w latach 20. xx wieku przypominał wcześniejszy spór kuzyna Sadgera z Karlem Krausem. W obu przypadkach biografowi zarzucano nieuzasadnione ujawnianie faktów z życia prywatnego i skłonność do konfabulacji [Le Rider 2000: 152-153]. 
wydaną w 1931 roku pt. Freud and his Time. Zebrane refleksje o ruchu psychoanalitycznym stały się przedmiotem jego autobiografii Freud and the Child Women. The Memoirs of Fritz Wittels wydanej pośmiertnie [Wittels 1995].

Wittelsowi pisanie biografii Freuda posłużyło przede wszystkim do wyłożenia subiektywnych refleksji na temat środowiska freudystów. Z kolei dla Jonesa głównym celem biografii było objaśnienie teorii psychoanalitycznej. Dzięki rekonstrukcji historycznego rozwoju psychoanalizy teoria freudowska miała według niego stać się bardziej zrozumiała ${ }^{4}$. Z podobnego założenia wyszedł sam Freud, kiedy pisał Wizerunek wtasny opublikowany w $1925 \mathrm{roku}^{5}$. Przedstawił w nim narodziny i rozwój myśli psychoanalitycznej. Już wcześniej wydał również krótką biografię ruchu psychoanalitycznego, będącą jednocześnie szkicem autobiograficznym [Freud 1914]. Zanim jeszcze stał się przedmiotem biografii, Freud sam siebie czynił obiektem autobiograficznego zapisu. W tym kontekście zastanawia wprowadzone przez Jonesa rozróżnienie na teorię i życie jej twórcy. Oddzielenie tego, co intymne (życie), od tego, co publiczne (dzieło), widoczne już w tytule biografii jego autorstwa, uznać należy za błąd.

Według Jonesa freudowska sygnatura nie umożliwia przekroczenia przepaści między ciałem (samo życie) a korpusem (zbiór opublikowanych dzieł) psychoanalizy, lecz ją pogłębia. Dla autora The Life and Work of Sigmund Freud psychoanaliza (a więc metoda terapeutyczna i teoria) narodziła się z kartezjańskiego umysłu pozbawionego ciała, z przebłysku geniuszu odseparowanego od życia codziennego. W tym duchu bronił podziału na prywatne życie Freuda i jego zawodową działalność. Inaczej do omawianego problemu odniósł się Jacques Derrida [1985: 1-39], kiedy

We wstępie do pracy The Life and Work of Sigmund Freud Jones [1962: 11-12, 25] zauważył, że twórca psychoanalizy najprawdopodobniej nie zaaprobowałby pomysłu spisania jego biografii; według niego żałował odsłonięcia autobiograficznych faktów w swych dziełach teoretycznych.

5 Niespełna stustronicowy tekst poświęcony rozwojowi własnej teorii po raz pierwszy ukazał się w czwartym tomie Medycyny w wizerunkach własnych w 1924 roku, a w niecałe dziesięć lat później w polskim przekładzie Henryka Załszupina [Freud 2017]. 
pisał o dynamis - niestabilnej granicy między dziełem a życiem, domagającej się szczególnej uwagi i analizy. W cyklu wykładów na Uniwersytecie w Montrealu w październiku 1979 roku francuski filozof przedstawił koncepcję „otobiografii”, będącej zarówno traktatem filozoficznym, jak i dziełem z obszaru intymistyki, na podstawie Ecce homo Fryderyka Nietzschego ${ }^{6}$. Według francuskiego filozofa spojrzenie na sygnaturę autora nie może opierać się na wyłącznej analizie filozoficznego systemu ani też ograniczać się do rozpoznania czynników zewnętrznych na niego wpływających. Dynamis, wyznaczona przez patriarchalne prawo, stanowi podstawę działania archiwum (przestrzeni archonta) i domaga się krytycznego spojrzenia oraz przekroczenia. Jak zauważa Derrida, obok prac Nietzschego i Sørena Kierkegaarda to właśnie dzieło Freuda stanowi zarazem korpus i ciało psychoanalizy - życie nierozerwalnie splotło się $\mathrm{w}$ nim z teorią, nauka z intymistyką, medycyna zaś z filozofią i literaturą [Derrida 1985: 6-18]7.

\section{Opis przypadku. Klinika, literatura i intymistyka}

Publikacja Objaśniania marzeń sennych w 1900 roku naznaczyła dalszy los psychoanalizy jako teorii interdyscyplinarnej, łączącej odrębne dziedziny wiedzy. Sam Freud [2015: 10] podsunął czytelnikom takie rozumienie swej pracy, kiedy we wstępie do drugiego wydania Traumdeutung pisat:

Dla mnie książka ta ma jednak jeszcze jedno znaczenie subiektywne - pojąlem to dopiero wtedy, gdy ukończyłem pracę nad nią, okazało się bowiem, że jako reakcja na śmierć mego ojca [...] stanowi ona część mojej autoanalizy. Kiedy to zrozumiałem, poczułem się niezdolny do zacierania śladów, jakie pozostawiło we mnie to wydarzenie $[\ldots]$.

6 Otobiografia, w ujęciu Derridy, jest dosłownie dziełem przyszłości - tekstem, którego sygnatura (to, co legitymizuje książkę, czyni zapis dziełem) ujawnia się dopiero w jego przyszłej lekturze.

7 O kwestii władzy i archiwum oraz klasyfikacji dzieł Freuda Derrida [2016] mówił więcej podczas wykładu wygłoszonego w 1994 roku w Muzeum Freuda w Londynie. 
Poświęcając się interpretowaniu własnych snów, Freud uczynił z siebie przedmiot i podmiot badania. Jak zauważa Anzieu, to właśnie korespondencja z Wilhelmem Fließem, prowadzona w tym samym okresie, pozwala zrekonstruować kolejne etapy freudowskiej praktyki introspekcji, stopniowo przekształconej przez niego w autoanalizę. Jednocześnie decyzja o publikacji badań przeprowadzonych na sobie samym, w przypadku lekarza zmagającego się z niedocenieniem i wykluczeniem w środowiskach lekarskich ${ }^{8}$, wiązała się nie tylko z odwagą, lecz także z jednoznaczną próbą zakwestionowania granic instytucjonalnie definiowanej naukowości ${ }^{9}$. We wstępie do pierwszego wydania Objaśniania marzeń sennych Freud [2015: 7-8] zapisał:

Jeśli zaś chodzi o opowiadanie własnych marzeń sennych, okazało się, że nierozłącznie wiąże się z tym fakt, iż wydaję na pastwę obcych spojrzeń więcej intymnych szczególów mego życia psychicznego, niż byłoby to konieczne, zważywszy na me zadanie jako autora, który nie jest poetą, lecz badaczem natury. Było to dla mnie przykre, okazało się jednak nieuniknione, podporządkowałem się więc tej konieczności, nie chciałem bowiem wyrzec się możliwości udowodnienia prawdziwości wyników mych badań psychologicznych.

Świadom ryzyka pisania pracy łączącej elementy rozprawy naukowej z intymistyką, Freud zdawał się jednoznaczenie rozpoznawać niemożność dojścia do prawdy psychologicznej bez zniesienia arbitralnego podziału na prywatne i publiczne. Sander L. Gilman [1993] w dziele Freud, Race, and Gender. z małym zainteresowaniem. (W przeciągu sześciu lat sprzedano jedynie trzysta pięćdziesiąt jeden egzemplarzy). Dla porównania biograf podaje, że Origin of Species Charlesa Darwina, dzieło opublikowane 24 listopada 1859 roku, sprzedało się prawie w całości w jeden wieczór (tysiąc dwieście pięćdziesiąt kopii). Gay [1989: 3-4] podkreśla też, że już sam tytuł dzieła Freuda był subwersywny; kojarzył się bowiem z ezoteryką, nie zaś z traktatem naukowym. 
Jak zauważa Le Rider, nowa nauka narodziła się nie tylko jako efekt pracy z pacjentkami i pacjentami, w dużym stopniu opartej na praktyce oralnej (rozmowie i opowiadaniu), lecz również dzięki technikom codziennego zapisu: prowadzeniu notatników dotyczących pacjentów, własnej autoanalizie [Le Rider 2000: $85-86]^{10}$, zapiskom poświęconym przyjmowanym wizytom czy wydatkom. Notatniki i kroniki domowe Freuda (częściowo ciągle w rękopisach) stały się podstawą kolejnej, obok talking cure, metody psychoanalitycznej. Tym razem nie została ona oparta na opowiadaniu, lecz na zapisie ${ }^{11}$. Le Rider [2000: 89] zauważa, że do tekstów z pogranicza intymistyki i nauki Freud przeniósł model analizy psychoanalitycznej polegający na spotkaniu i rozmowie dwóch podmiotów: pacjenta i analityka. Zarówno w autoanalizie, jak i w autobiografii piszący jest jednocześnie przedmiotem i podmiotem tekstu - poddający się samoobserwacji i piszący autobiografię w procesie (auto)zapisywania stają się swymi własnymi biografami.

\section{Biografia, słowo i ucho. Historia życia jako opowieść} o początkach

Włoska badaczka Adriana Cavarero [1997] w pracy Tu che mi guardi, tu che mi racconti. Filosofia della narrazione zastanawiała się, czy na

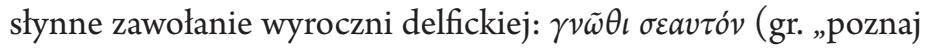
samego siebie") lepiej odpowiada opowieść snuta o samym sobie, czy raczej biografia. Badaczka stwierdziła, że: „Na pytanie «kim jestem?» nie odpowiada właściwa autobiografia, lecz moja historia opowiedziana przez kogoś innego" [Cavarero 2004: 41]. Dla Cavarero biografia była gatunkiem polifonicznym, opartym na dwugłosie opowiadającego i słuchającego. Przyglądając się Królowi Edypowi Sofoklesa, dowodziła nielinearności tworzonej w ten sposób historii czyjegoś życia. W dramacie pojawiły się bowiem nie analizuje własne sny [Rider 2000: 85-86]. 
dwie sprzeczne narracje: wszechwiedząca, zewnętrzna narracja mitu oraz wewnętrzna i myląca narracja aktorów.

Tytułowy Edyp poznaje własną historię przy pomocy zasłyszanych o sobie sprzecznych historii, nie zaś nie w efekcie introspekcji. Cavarero [2004: 13] zauważa:

W rzeczywistości dla Edypa to, kim jest, wynika z historii jego życia, którą przedstawiają mu inni. Ta historia opowiadana jest na wiele głosów, jako że powstaje $\mathrm{z}$ fragmentów narracji, $[. .$. układając je w dramatyczny kolaż.

W podobny sposób napięcie między autobiografią a biografią rozwija Derrida. Wychodząc od cytatu z Nietzscheańskiego Tako rzecze Zaratustra ${ }^{12}$, zauważa, że autobiografia może zaistnieć dopiero wówczas, gdy przekształci się w „otobiografię”, tzn. zostanie wysłuchana i zrozumiana przez kogoś, kto nie jest podmiotem opowiadanej historii. W ten sposób otobiografia, podobnie jak biografia, rozumiana jako gatunek dialogiczny i otwarty na przyszłe odczytania, daje większą szansę na poznanie samego siebie niż autobiografia.

\section{Biografia Freuda jako patograficzny opis pewnego przypadku}

Sześć lat po biografii autorstwa Wittelsa w wydawnictwie Ernsta Wengrafa ukazał się kolejny szkic poświęcony ojcu psychoanalizy pióra Sadgera. Mimo że dzieło Sigmund Freud. Persönliche Erinnerungen było najważniejszą pracą autorstwa pochodzącego z Nowego Sandomierza psychoanalityka, to ani Freud, ani inni jego uczniowie (w tym przyszli biografowie) najprawdopodobniej

Derrida wychodzi od następującego fragmentu z dzieła niemieckiego filozofa: „Gdy powracając z mej samotni, po raz pierwszy przechodziłem przez ten most, nie dowierzałem oczom własnym: spoglądam, patrzę i mówię wreszcie: «Toż to jest ucho! Ucho wielkości człowieka!». Przyglądam się jeszcze lepiej: pod uchem porusza się coś żałośnie małego, ubożuchnego i mizernego. I rzeczywiście potworne uszysko osadzone było na malutkiej, cienkiej łodyżce; łodyżka ta była - człowiekiem!" [Nietzsche 2004: 100].

Oũ ৎ w starożytnej grece oznaczało 'ucho'. 
go nie czytali [Sadger 2005: xli-xlii]. Przez kolejne siedemdziesiąt pięć lat manuskrypt zatytułowany Erinnerungen an Freud uznawano za zaginiony i nieopublikowany [Mühlleitner 1992: 282-283]. Dopiero dzięki staraniom Alana Dundesa udało się odnaleźć pojedynczy egzemplarz wydania z 1930 roku, który stał się podstawą współczesnej edycji z 2005 roku.

Sadger urodził się w 1967 roku w Nowym Sandomierzu, mieście znajdującym się na obszarze ówczesnej Galicji. Jeszcze jako dziecko przyszły psychoanalityk przeniósł się wraz z rodzicami Miriam i Herschem Sadgerami do Wiednia, gdzie w 1885 roku ukończył męskie gimnazjum. Wkrótce potem rozpoczął studia medyczne na Uniwersytecie Wiedeńskim. Po ich ukończeniu w 1891 roku podjął praktykę jako neurolog, specjalizując się w hydroterapii. W tym okresie Sadger inspirował się odkryciami Vinzenza Priessnitza (twórcy nowoczesnej hydroterapii), którego poznał w czasie stażu w kurorcie Gräfenberg. Początkowo publikował w czasopiśmie „Blätter fur klinische Hydroterapie und verwandte Heilmethoden"14. W kolejnych latach dołączył do towarzystwa naukowego Gesellschaft fur physikalische Therapie in Wien, dla którego przygotował dwa obszerne artykuły poświęcone balneoterapii i hydroterapii zamieszczone w zbiorowej publikacji Medizinische Handlexikon für praktische Ärzte redagowanej przez Maxa Kahana.

Sadger [2005: 7] należał do najstarszych uczniów Freuda uczęszczających na jego wykłady prowadzone jeszcze pod koniec XIX wieku [zob. Mühlleitner 1992: 282]. Przyszły freudysta zapoznał się z wczesnymi odkryciami twórcy psychoanalizy na uniwersyteckich kursach w semestrze zimowym 1895/1896, które kontynuował w latach 1896 i 1898, a następnie między 1903 i 1904 rokiem. 14 listopada 1906 roku Freud zaproponowal jego kandydaturę do Środowego Towarzystwa Psychologicznego założonego w 1902 roku $^{15}$. Od początku swej działalności w ruchu Sadger zajmował się przede wszystkim nienormatywną seksualnością. Jego prekursorskie badania dotyczyły masochizmu, narcyzmu i męskiego homo- 
seksualizmu [May 2003]. W Wiedeńskim Towarzystwie Psychoanalitycznym Sadger najaktywniej działał do wybuchu I wojny światowej. Po wojnie związał się ze środowiskiem skupionym wokół Ottona Fenichela, z którym współtworzył Akademischen Vereins judischer Medizinier organizujące seminaria seksuologiczne w latach 1919-1921. Wykształciły one młodszą generację psychoanalityków, w tym przedstawicieli późniejszej „freudowskiej lewicy”.

Przed wstąpieniem do Wiedeńskiego Towarzystwa Psychoanalitycznego Sadger publikował psychologiczne portrety poetów i pisarzy. Jego „patografie” plasowały się na granicy biografii i klasycznego opisu przypadku, stając się hybrydycznymi formami literackimi stworzonymi z połączenia języka ówczesnej psychiatrii i literaturoznawstwa [Sadger 1912: 158-175]. Między 1894 a 1895 rokiem Sadger opublikował w „Allgemeine Zeitung” kilka artykułów poświęconych Henrykowi Ibsenowi. Wkrótce powstały również jego opracowania dotyczące psychologii i psychopatologii twórczej na przykładzie życia i prac Johanna Wolfganga von Goethego, Konrada Ferdinanda Meyera, Heinricha von Kleista i Friedricha Hebbela [Sadger 1877, 1908, 1910, 1920]. Swoje pierwsze wystąpienie w Środowym Towarzystwie Psychoanalitycznym poświęcił portretowi psychologicznemu Nikolasa Lenaua na podstawie jego korespondencji z Sophią Löwenthal ${ }^{17}$. Oprócz pisarzy i poetów Sadger analizował również bohaterów literackich, przyglądając się ich fikcyjnym biografiom. Na jednym z posiedzeń Środowego Towarzystwa Psychologicznego ${ }^{18}$ Stekel podkreślit, że to Sadger był autorem rewelatorskiej interpretacji biografii Don Juana, zgodnie z którą wyjaśnienia jego satyriasis szukano w niespełnionym pragnieniu homoseksualnym ${ }^{19}$.

Na przykład Wilhelma Reicha, który był analizowany przez Sadgera. O psychoanalitykach związanych z ruchami lewicowymi zob. pracę Paula A. Robinsona [1970] The Freudian Left. Wilhelm Reich, Geza Roheim, Herbert Marcuse.

Zapisy ze wszystkich spotkań Środowego Towarzystwa Psychologicznego notowane przez Ottona Ranka zostały wydane w angielskim przekładzie pt. Minutes of the Vienna Psychoanalytic w czterech tomach. Pierwszy referat Sadgera zob. Nunberg, Federn, red. 1962: 62-68. 17 lutego 1909 roku [Nunberg, Federn, red. 1967: 157].

19 Psychoanalityczne studia poświęcone Don Juanowi tworzył również Rank. Zostały one wydane pt. Die Don Juan-Gestalt. Ein Beitrag zum Verständnis der 
Wśród psychoanalityków Sadgerowskie patografie odczytywane były zarówno jako psychologiczne portrety wielkich twórców, pozwalające na pogłębioną interpretację ich działalności dzięki odsłanianiu tajników biograficznych, jak i obszerne opisy przypadków - a więc efekt analizy przeprowadzonej na pacjencie przez lekarza. Jeżeli potraktować stworzone przez Sadgera patografie jako psychoanalityczne opisy przypadków, a zarazem biografie ich bohaterów, to badacz operował większym warsztatem pisarza biografa niż jakikolwiek inny uczeń twórcy psychoanalizy, nim przystąpił do pisania dzieła poświęconego Freudowi.

Do opowieści o Freudzie Sadger podszedł podobnie jak do przypadku Kleista czy Goethego, czyniąc z autora Psychopatologii zycia codziennego swego kolejnego pacjenta. W Sigmund Freud. Persönliche Erinnerungen interesowały go przede wszystkim wydarzenia związane z Freudem, których był bezpośrednim świadkiem. W ten sposób zaproponował biograficzny tekst oparty na „obserwacji uczestniczącej” [Sadger 2005: xlv-xli]. Dla Sadgera istotne były nie „suche” fakty z życia mistrza czy treść jego opublikowanych dzieł, lecz własne refleksje i osobiste wspomnienia z licznych spotkań z Freudem. Jego wywód został oparty przede wszystkim na źródłach oralnych (zapamiętanych wypowiedziach i komentarzach autora Totemu i tabu), nie zaś materialnych (chociażby własnej korespondencji z Freudem). Opowieść o Freudzie potraktował jako analizę, której poddał się autor Objaśniania marzeń sen$n y \mathrm{ch}^{20}$.

Większą część Sigmund Freud. Persönliche Erinnerungen stanowią uwagi dotyczące charakteru Freuda. Sadger zaproponował ówczesnym czytelnikom patograficzny opis osobowości twórcy psychoanalizy oparty na jego stosunku do uczniów i członków Wiedeńskiego Towarzystwa Psychoanalitycznego. Bardziej niż kariera Freuda lekarza czy Freuda filozofa interesowało go nakreślenie portretu twórcy psychoanalizy jako nauczyciela. Swój niezwykły sukces Freud zawdzięczał nie tylko charyzmie i talentowi

sozialen Funktion der Dichtkunst [Rank 1922: 142-196] oraz Don Juan und Leporello [Rank 1927: 172-182].

Freud, tak jak Sadger, nie poddał się analizie [Mühlleitner 1992: 282]. 
dobrego mówcy, lecz przede wszystkim pracy innych - pomysłom i odkryciom swoich uczniów i młodych współpracowników [Sadger 2005: 13-19, 23]. Choć Sadger nie próbował podważyć jego geniuszu, podkreślit, że następcy Freuda również wysuwali nowatorskie propozycje teoretyczne, które sporadycznie spotykały się $\mathrm{z}$ aprobatą mistrza i najczęściej były przez niego uznawane za efekt własnej pracy.

Mimo że Sadger [2005: 40], jak sam pisze, chciał widzieć we Freudzie dobrego nauczyciela i kochającego ojca, ten okazał się tyranem. Podkreślając jego emocjonalną niestabilność, nieumiejętność zapanowania nad własnymi afektami oraz manię wielkości, zrównał go z Ottonem von Bismarckiem oraz zdiagnozowal jako narcyza i sadystę. Dla Freuda - pisał - już na wczesnym etapie życia istotne było doświadczenie wykluczenia, naznaczające całą jego przyszłą karierę zawodową. Jako członek Wiedeńskiego Towarzystwa Psychoanalitycznego praktycznie przez większą część jego istnienia Sadger obserwował narastające konflikty między twórcą psychoanalizy a jego najbliższymi uczniami: Alfredem Adlerem, Carlem Gustavem Jungiem, Wilhelmem Steklem i Ottonem Rankiem. Podkreślił też, że chociaż Freud był mistrzem pozyskiwania talentów, nigdy nie potrafil ich przy sobie zatrzymać [Sadger 2005: 35]. To właśnie jego najwierniejsi i najbardziej zaufani uczniowie spotkali się z jego strony z najsurowszym traktowaniem.

Podstawowym założeniem biografii Freuda, podobnie jak pozostałych tekstów Sadgera poświęconych analizie patologicznych elementów psychiki wielkich poetów, było nakreślenie wiernego portretu charakterologicznego twórcy na podstawie interpretacji jego zachowań. Kolejnym krokiem było poddanie go analizie psychoanalitycznej, w założeniu mającej prowadzić do odsłonięcia stłumionych i wypartych treści. W tym wypadku Sadger, podobnie jak Josef Breuer w terapii Anny O., pozwolił Freudowi mówić własnym głosem [Freud, Breuer 2008: 44-46]. Analizował przede wszystkim jego twierdzenia o samym sobie na podstawie dwóch

W rozdziale poświęconym Freudowi jako nauczycielowi Sadger podkreślił, że to on w rzeczywistości był autorem koncepcji przejętych później przez Freuda [Sadger 2005: 23]. Zauważył też, że czasem twórca psychoanalizy przypisywał innym własne odkrycia, jak w przypadku Carla Gustava Junga [Sadger 2005: 33]. 
szkiców autobiograficznych: Zur Geschichte der Psychoanalytischen Bewegung oraz Wizerunku wtasnego. Eksperymentując z opisem przypadku, Sadger poszedł w ślady Freudowskiego tekstu poświęconego Danielowi Paulowi Schreberowi, który opierał się na autobiografii niemieckiego sędziego [Freud 2009].

Sadger poddał analizie fragment $\mathrm{z}$ Wizerunku własnego, w którym autor przedstawił historię swoich narodzin oraz prześledził rodziną genealogię:

Urodziłem się 6 maja 1856 roku we Freibergu na Morawach, małej mieścinie w obecnej Czechosłowacji. Rodzice moi byli Żydami; ja także pozostałem Żydem. Rodzina moja ze strony ojca żyła przez długi czas, o ile dobrze wiem, nad Renem (w Kolonii), skąd w XIV czy XV wieku, wskutek prześladowania Żydów, uciekła na wschód i w ciągu XIX wieku zawędrowała z powrotem, przez Litwę i Galicję, do Austrii Niemieckiej. [Freud 2017: 6]

Dla autora Sigmund Freud. Persönliche Erinnerungen, inaczej niż dla Jonesa czy Petera Gaya (autorów dwóch najobszerniejszych biografii poświęconych Freudowi), nie druga, lecz pierwsza część przywołanego fragmentu zdawała się istotniejsza. Podczas gdy późniejsi biografowie koncentrowali się na aporiach związanych z pochodzeniem rodziny Freuda, Sadger [2005: 90-91] większe znaczenie przypisał kwestii jego żydowskich korzeni.

Jak zauważa Adriana Cavarero [2004: 10-12], celem biografii jest nie tylko stworzenie spójnej narracji o życiu jednostki, lecz także powtórne zaświadczenie o istnieniu podmiotu, dzięki rekonstrukcji i przypomnieniu jego początków. Mimo że zadaniem zarówno autobiografa, jak i biografa jest sięgnięcie do korzeni bohatera tekstu, tylko ostatniemu udaje się powiedzieć coś, czego spisujący własną historię nie może odgadnąć. Włoska badaczka stwierdza, że los Edypa poszukującego prawdy o swym pochodzeniu jest w istocie uniwersalną opowieścią o kondycji ludzkiej [Cavarero 2004: 12-13]. Podobnie jak w Derridiańskiej otobiografii także u Cavarero prawdę o sobie podmiot rozpoznaje jedynie w opowieści innych. W tym świetle celem pisania biografii Freuda 
nie była rekonstrukcja historii jego życia na podstawie treści wynikającej z własnych wypowiedzi, lecz raczej odkrycie tego, co nie zostało w nich zawarte wprost bądź w ogóle wyrażone. Jeśli autobiografia, tak jak definiował ją Paul de Man [1986], była sposobem na od-twarzanie, a więc rozmywanie tożsamości podmiotu w tekście przy pomocy tworzenia nowych tożsamości i skrywania „ja” za maskami z fragmentów wytwarzanej przez siebie narracji, to zadaniem biografa jest ich rozbicie. W przypadku Sigmund Freud. Persönliche Erinnerungen biograf wszedł w rolę analityka i podjął dialog z własnym pacjentem, aby wydobyć z jego (auto)narracji to, co zostało stłumione.

Według Sadgera pozostawione przez Freuda autobiografie raczej mówią o jego psychicznym życiu niż świadczą o rzeczywistych wydarzeniach z jego historii. Biografa nie interesowało, czy rodzina Freuda przywędrowała z Niemiec do Austro-Węgier, czy wywodziła się ze wschodnich terenów Galicji ${ }^{22}$. Istotny był dla niego fakt, że twórca psychoanalizy dopatrywał się korzeni swej rodziny w historii i kulturze niemieckiej, nie chcąc wpisać się w obraz galicyjskiego Żyda ${ }^{23}$. Jak zauważa Sander L. Gilman, Żydzi emigrujący ze wschodu do zachodnich metropolii traktowani byli tam jak obcy, którym przypisano wszystkie cechy kojarzone z dzikością i społeczeństwami nierozwiniętymi. W 2. połowie XIX wieku Żydów często porównywano do Afrykanów; określano ich niekiedy mianem „białych czarnuchów”, próbując dowieść w ten sposób zajmowania przez nich niższego szczebla w procesie ewolucji [Gilman 1993: 18-19]. Gilman dodaje, że dla wielu Żydów zasymilowanych z kulturą zachodnią Ostjuden zdawali się podobni do mieszkańców Czarnego Lądu. Ich „pierwotna kultura” w oczach Europejczyka dowodziła postępu stworzonej przez niego cywilizacji [Gilman 1993: 253].

Ojciec Freuda urodził się w mieście Tyśmienica, zaś matka pochodziła z północno-wschodniej Galicji, z miasta Brody [Gay 1989: 31-33].

23 Pisze o tym w kilku pracach Sander L. Gilman; zwłaszcza w tekście Freud, Race, and Gender; Jewish Self-Hatred. Anti-Semitism and the Hidden Language of the Jews oraz w Black Bodies, White Bodies. Towards the Iconography of Female Sexuality in Late Nineteenth-Century Art [Gilman 1985, 1986, 1993]. 
Zachodnich Żydów od galicyjskich imigrantów miał odróżniać nie tylko światopogląd, wygląd zewnętrzny czy zachowanie, lecz także język. W niemieckiej wyobraźni, obok hebrajskiego i jidysz, Żydzi posługiwali się również specyficzną mową określaną jako mauscheln, będącą zlepkiem słowa i gestu [Gilman 1986: 139-148]. Jak twierdzi Gilman [1986: 139], mauscheln było fantazmatycznym tworem przypisanym Żydom w celu podkreślenia ich kulturowej odrębności. Nie bez powodu Sadger tak wiele miejsca poświęcił językowi Freuda. Szczególną uwagę zwrócił na poprawność jego niemczyzny i wyrafinowany styl publikowanych tekstów [Sadger 2005: 26-29]. Bezbłędny niemiecki autora Totemu i tabu umożliwił mu odsunięcie od siebie figury Ostjude oraz wyznaczenie nieprzekraczalnej granicy między sobą a przybyszami z Galicji [Mühlleitner, Reichymayr 1997]. Sadger zauważa, że Freud, liczył na karierę akademicką i społeczny awans, gdyż wierzył w możliwość pełnej asymilacji. Szybko jednak dostrzegł, że zyskanie statusu pełnoprawnego obywatela jest jedynie złudzeniem:

Uniwersytet, na który wstąpiłem w r. 1873, przyniósł mi zrazu dotkliwe rozczarowania. Przede wszystkim ubodło mnie to, że powinienem uważać się za mniej wartościowego i narodowo przynależnego, ponieważ byłem Żydem. Pierwsze odrzuciłem z całą stanowczością. Nigdy nie pojąłem, dlaczego miałbym się wstydzić mojego pochodzenia czy rasy - jak wówczas zaczęto się wyrażać. Z nieprzyjęcia mnie do narodowej wspólnoty zrezygnowałem bez wielkiego żalu. Mniemałem, że i bez tego zaszeregowania znaleźć się musi dla gorliwego współpracownika małe miejsce w ramach ludzkości. [Freud 2017: 7-8]

Odnosząc się do powyższego opisu doświadczenia antysemityzmu, Sadger zarzucił jego autorowi niewystarczające podejmowanie owego tematu w późniejszych latach. Według niego bowiem Freud starał się wymazać zarówno wpływ agresywnego antysemityzmu na własną karierę, jak i na późniejsze losy psychoanalizy [Sadger 2005: 90-100]. W tym punkcie intuicje oraz obserwacje Sadgera w pełni pokrywają się z rozpoznaniami Gilmana [1993: 3-11]. 
Chociaż Freud [2015: 179-180] w autoanalizie podjąt problem własnego wykluczenia oraz związanego $\mathrm{z}$ nim poczucia upokorzenia, opisany w Objaśnianiu marzeń sennych, to Sadger zarzucił mu odrzucenie żydowskiej tożsamości oraz stworzenie nieprawdziwej historii o własnych początkach. Według niego autobiograficzna opowieść posłużyła twórcy psychoanalizy jako maska, pod którą kryła się tłumiona niechęć do samego siebie. Była ona związana nie tyle z pochodzeniem, ile z rasą - zinternalizowanym obrazem Żyda, stale obecnym w imaginarium kultury europejskiej. W pracy Jewish Self-Hatred. Anti-Semitism and the Hidden Language of the Jews Gilman [1986: 1-7] opisał zjawisko „samo-nienawiści” (self-hatred) właśnie jako efekt przyjęcia przez wykluczony podmiot krzywdzącego obrazu siebie stworzonego przez grupę większościową i wykorzystywanego przez nią do postawienia granicy między sobą a innym. Według Sadgera Freudowska samo-nienawiść najwyraźniej objawiła się w jego jednoczesnej niechęci do współpracowników z koła wiedeńskiego i fascynacji Jungiem [Sadger 2005: 70-72]. Sądził, że relacja twórcy psychoanalizy ze szwajcarskim lekarzem nie była czysto zawodowa, a uczucia, jakie Jung wzbudzał we Freudzie, związane byly przede wszystkim z kwestią rasy. Jeśli autor Totemu i tabu kiedykolwiek pragnął, aby psychoanaliza stała się nauką uniwersalną, to pozyskanie nieżydowskich naukowców było kwestią zasadniczą. Rola Junga w środowisku psychoanalitycznym miała polegać na zrzuceniu z freudyzmu piętna rasy; miała gwarantować przejście od „żydowskiej teorii” do uniwersalnej nauki [Sadger 2005: 98-99].

\section{Biografia Freuda jako autoanalityczny opis przypadku}

W poprzedniej części tekstu starałam się pokazać, w jaki sposób gatunek biograficzny przekształcił się w klasyczny opis przypadku; pisałam o związku patografii - próby psychoanalizy przedmiotu opowieści - z tworzeniem narracji o życiu innego. Biografię Freuda potraktowałam analogicznie do publikowanych przez Sadgera analiz pacjentów i poetów. Jednak zarówno Freud, jak i Sadger, tworząc narracje o analizowanych, wchodzili w rolę zwierzającego się podmiotu. W tym świetle patografia jest w równym stopniu 
opowieścią o innym co autobiografią. Leigh Gilmore, analizując przypadek Dory, zauważyła, że historia pacjentki Freuda była jedynie pretekstem i okazją do przedstawienia jego własnej opowieści. Freud, rekonstruując opowieść Idy Bauer, stworzył narrację, w której sam stał się podmiotem autobiografii [Gilmore 1994: 57]. Podobne stwierdzenie można odnieść do Sigmund Freud. Persönliche Erinnerungen - dzieła, w którym, odwrotnie niż w ujęciu Cavarero, historia życia innego posłużyła do opowiedzenia o sobie samym. De Man [2000: 310-312] celnie zauważyl, że piszący autobiografię traktuje tekst jako środek służący rozszczelnieniu tożsamości i uwolnieniu się spod jarzma hegemonicznie narzuconego „ja”. W tym świetle analiza Sadgera okazuje się specyficzną formą autoanalizy przeprowadzoną przez dwie osoby, nie zaś w pojedynkę. Autobiografia traktowana jako sztuka gry z maską w tym wypadku staje się próbą opowiedzenia o sobie dzięki rekonstrukcji i interpretacji historii innego. Uważna lektura Sigmund Freud. Persönliche Erinnerungen pozwala dostrzec, że spod portretu twórcy psychoanalizy wyłania się wizerunek jego biografa.

Dlaczego Sadger zdecydował się jednak przedstawić własną autobiografię, przyjmując maskę Freuda? Kiedy szukamy odpowiedzi w poststrukturalistycznym ujęciu autora Allegories of Reading, strategia autora Sigmund Freud. Persönliche Erinnerungen może wydawać się zabawą z gatunkiem biografii. Gra z napięciami między opisem przypadku, patografią a autobiografią ujawniłaby wówczas granice powyższych gatunków, dowodząc jednocześnie ich niestabilności. Linda Haverty Rugg [1997: 133-187] w pracy Picturing Ourselves zwraca jednak uwagę na fakt pomijania przez postmodernistów kontekstu pozatekstowego. Dla de Mana każdy autor i autorka spisujący autobiografię bawi się znaczeniami w ramach tekstu, tworząc dla siebie nowe tożsamości. W ten sposób - pisze Rugg [1997: 179] - nie dostrzega uwarunkowań pozatekstowych, zasadniczych w przypadku autorów codziennie zmagających się z wykluczeniem. Znaczenie, jakie Sadger przypisuje pochodzeniu Freuda, jego uwagi poświęcone analizie „żydowskości” psychoanalizy czy podejrzliwość wobec „aryjskości” Junga, muszą zostać odczytane w kontekście antysemityzmu kształtującego życie nie tylko Freuda, lecz także autora jego biografii. Twórca dojrzałej 
formy patografii przyjął taką strategię pisarską, aby z losów twórcy psychoanalizy uczynić negatyw własnego doświadczenia.

Mimo wieloletniej współpracy z Freudem, Sadger do dziś pozostaje jedną z najbardziej enigmatycznych postaci wiedeńskiego środowiska twórcy psychoanalizy. W latach swej działalności w Wiedeńskim Towarzystwie Psychoanalitycznym (1906-1933) nie tylko nie spotkał się ze szczególnym uznaniem ze strony innych współpracowników, ale został wręcz utrwalony w ich wspomnieniach jako postać nieprzyjemna i odpychająca. Już pierwsza biografia Freuda, autorstwa Wittelsa, dostarcza istotnych informacji o stosunku autora Totemu i tabu do jednego ze swych najwierniejszych uczniów. Kuzyn Sadgera wspomina, że pierwsza wzmianka Freuda o autorze Sigmund Freud. Persönliche Erinnerungen pojawia się w Objaśnianiu marzeń sennych [Freud 2015: 258]. Już wówczas twórca psychoanalizy wątpił w teksty jego autorstwa, uważając je za słabo napisane [Sadger 2005: xv]. Z kolei Ernest Jones wspomina, że Sadger należał do grupy najbardziej „problematycznych” członków WTP, stale walczących o miłość „ojca” [Jones 1962: 399]. W swej autobiografii dodaje również, że często zachowywał się niekulturalnie, wręcz ordynarnie [Jones 1959: 168-169]. Biograf Freuda potrafił w przygodnym miejscu wypytać dopiero co spotkaną damę o jej życie intymne. Uwaga ta jest szczególnie istotna, bowiem pokazuje, że dla angielskiego psychoanalityka Sadger zarówno „nie dorastał” do zachodniej kultury (brak manier), jak i zachowywał się wulgarnie (niedyskretne pytania dotyczące seksualności). Podobnie o analityku pisała Deutsch, zwracając uwagę na jego nadmierne zainteresowanie seksem. Dla polskiej psychoanalityczki Sadger był „perwersyjny”; także sam jego obraz wiązał się dla niej z odczuciem wstrętu, kiedy pisała o jego brudnym gabinecie i niezadbanych paznokciach [Roazen 1991: 159; Sadger 2005: xxxv].

W środowisku wykształconych i zasymilowanych lekarzy pochodzenia żydowskiego Sadgerowi przypisano pozycję odmieńca i dzikusa. Z brudnymi paznokciami i rozerotyzowanym spojrzeniem kojarzył się z popularną wówczas antysemicką figurą Żyda jako zepsutego i groźnego elementu. Jak stwierdza Gilman [1993: 12-48], jedną z głównych cech przypisanych Ostjude była nie 
tylko rasowa (i kulturowa) odmienność, lecz także zniewieściałość i homoseksualizm (najczęściej uznawany wówczas za perwersję). Zarówno Jones, jak i Deutsch stworzyli obraz Sadgera silnie nacechowany antysemityzmem; w ich opisach „inność” psychoanalityka przejawiała się zarówno na poziomie wyglądu (brud), zachowania (wulgarność), jak i działalności naukowej (główne zainteresowania badawcze dotyczyły właśnie homoseksualizmu). Lou Andreas-Salomé w swym dzienniku wspomina również środowe spotkania w wiedeńskim mieszkaniu Freuda, w czasie których Sadger prezentowal swoje referaty. Podobnie jak inni freudyści stwierdziła, że jego rozpoznania nie były interesujące, wybór tematów mało stymulujący, a same odczyty chaotyczne [Andreas-Salomé 1983: 24]. Analogicznie jak w wyobrażeniu o Ostjude także Sadgerowi przypisywano nieopanowanie języka „wyższej” kultury. Jego odmienność została skonstruowana wedle klucza antysemickiego, w którym różnica oparta była na kulturowo i rasowo dowodzonej inności. Sadger w opinii pierwszych psychoanalityków nie był erudytą, a jego podejście do nauki cechowała quasi-religijna ortodoksja. Freud w liście do Junga z 5 marca 1908 roku stwierdzil, że autor Sigmund Freud. Persönliche Erinnerungen traktował psychoanalizę niczym wiarę. Podobny sąd o nim wydał Karl Abraham, który w korespondencji z Maxem Eitingonem stwierdził z niechęcią, że Sadger zachowywał się wśród freudystów jak ortodoksyjny żyd.

W (auto)biografii Sadger nie pominął kwestii podejścia Freuda do judaizmu. Stwierdził też, że była to dla niego kwestia najtrudniejsza do opisania [Sadger 2005: 100]. Sam obsadzony w roli religijnego ortodoksa pisał o niechęci twórcy psychoanalizy do judaizmu oraz o jego zachowawczości względem syjonizmu. Według niego przyczyną zdystansowania Freuda względem obu grup był strach przed wykluczeniem. W wizji ortodoksyjnego żyda najpełniej objawiała się bowiem różnica między dzikością a cywilizacją [Gilman 1986: 141]. Freud, dowodząc, że badanych przez niego schorzeń nie można tłumaczyć według klucza rasowego czy klasowego, starał się uczynić z psychoanalizy naukę uniwersalną - jak zauważył Sadger, za wszelką cenę próbował oczyścić ją z „piętna rasy”. 
Jeśli pisanie biografii mogło służyć autorowi do przeprowadzenia autoanalizy, to pisanie o samo-nienawiści u Freuda odnosiło się również do autora powyższej diagnozy. Warto zapytać o to, $\mathrm{w}$ jakim stopniu sam Sadger rozpoznał u siebie problem internalizacji stereotypowego obrazu Żyda. Inaczej niż twórca psychoanalizy, dowodził on częściowej dziedziczności chorób psychicznych, przy czym niektóre z nich, przede wszystkim histeryczność i nadmierną nerwowość, przypisywał polskim Żydom [Nunberg, Federn, red. 1962: 58; Gilman 1993: 117]. Wbrew Freudowi (i większości jego współpracowników) autor Sigmund Freud. Persönliche Erinnerungen traktował homoseksualizm jako schorzenie możliwe do wyleczenia dzięki psychoanalizie. W swych badaniach nad seksualnością przyjął również nienaukową teorię Richarda von Krafft-Ebinga, według której wszelkie nienormatywne zachowania seksualne piętnowane były jako perwersje [Sadger 1914]. W ten sposób badania Sadgera opierały się na uwypukleniu różnicy między sobą (lekarz w pozycji władzy) a pacjentem, sprowadzonym do klinicznego przypadku (przedmiot badań) - granicy, którą zrodzona na przełomie wieków psychoanaliza starała się przekroczyć [Dean, red. 2001].

Brak uznania dla własnych teorii doprowadził Sadgera do decyzji o wystąpieniu z Wiedeńskiego Towarzystwa Psychoanalitycznego w $1933 \mathrm{roku}^{24}$. Biografia Freuda, obok pojedynczego tekstu poświęconego relacji dziecka z rodzicami [Sadger 1930], była jego ostatnim dziełem pisanym $w$ ramach ruchu psychoanalitycznego. Mimo że wprowadził do teorii psychoanalitycznej tak ważne dla niej pojęcie narcyzmu, a do 1930 roku opublikował w czasopismach psychoanalitycznych przeszło sto pięćdziesiąt artykułów naukowych i pięćdziesiąt recenzji, traktowany był jako badacz mało znaczący i nieciekawy. Jego dalsze losy, na tle innych freudystów, okazały się szczególnie tragiczne, bowiem jako jeden z nielicznych psychoanalityków zginął w Holokauście [Kirsner 2007]. W czasie akcji Reinhardt, 10 sierpnia 1942 roku, Sadger został deportowany do obozu koncentracyjnego w Terezinie, 
gdzie zmarł między 20 a 21 grudnia tego samego roku [Mühlleitner 1992: 283]. Sigmund Freud. Persönliche Erinnerungen nie tylko stanowią jego najważniejsze dzieło oraz jeden z najbardziej fascynujących tekstów poświęconych Freudowi, lecz także są przykładem tekstu literackiego badającego związki psychoanalizy z literaturą i intymistyką. Sadger w biografii Freuda pokazal, w jaki sposób klasyczny opis przypadku może czerpać z patografii, a sama patografia oprzeć się na biografii, ściśle związanej z autoanalizą i autobiografią.

\section{Bibliografia}

Andreas-Salomé Lou (1983), In der Schule bei Freud, Ullstein, Frankfurt am Main [Niemcy].

Anzieu Dider (1959), L'auto-analyse. Son rôle dans la découverte de la psychanalyse par Freud. Sa fonction en psychanalyse, Presses Universitaires de France, Paris [Francja].

Cavarero Adriana (1997), Tu che mi guardi, tu che mi racconti. Filosofia della narrazione, Feltrinelli, Milano [Włochy].

Cavarero Adriana (2004), Opowiedz mi moją historię, „Pamiętnik Literacki”, nr 95/3, s. 5-41.

Dean Tim, red. (2001), Psychoanalysis and Homosexuality, University of Chicago Press, Chicago [USA].

Derrida Jacques (1985), The Ear of the Other, ed. Christie V. McDonald, przeł. Avital Ronnel, Schocken Books, New York [USA].

Derrida Jacques (2016), Gorączka archiwum. Impresja Freudowska, przeł. Jakub Momro, IBL PAN, Warszawa.

Deutsch Helena (1973), Confrontations with Myself. An Epilogue, W.W. Norton \& Company, New York [USA].

Deutsch Helena (2008), Konfrontacja z sama sobą. Epilog, przeł. Adam Pluszka, Cyklady, Warszawa.

Freud Sigmund (1914), Zur Geschichte der Psychoanalytischen Bewegung, „Jahrbuch der Psychoanalyse”, nr 6, s. 207-260.

Freud Zygmunt, Józef Breuer (2008), Studia nad histeria, przeł. Robert Reszke, Wydawnictwo KR, Warszawa.

Freud Zygmunt (2009), Charakter i erotyka, przeł. Robert Reszke, Wydawnictwo KR, Warszawa.

Freud Zygmunt (2015), Objaśnianie marzeń sennych, przeł. Robert Reszke, Wydawnictwo KR, Warszawa. 
Freud Zygmunt (2017), Wizerunek własny, przeł. Henryk Załszupin, Vis-à-vis Etiuda, Kraków.

Gay Peter (1989), Freud. A Life for our Time, Anchor Books, New York [USA].

Gilman Sander L. (1985), Black Bodies, White Bodies. Towards the Iconography of Female Sexuality in Late Nineteenth-Century Art, Medicine and Literature, „Critical Inquiry”, vol. 12 (1), s. 204-242.

Gilman Sander L. (1986), Jewish Self-Hatred. Anti-Semitism and the Hidden Language of the Jews, Johns Hopkins University Press, Baltimore [USA].

Gilman Sander L. (1993), Freud, Race, and Gender, Pronceton University Press, Princeton [USA].

Gilmore Leigh (1994), Autobiographics. A Feminist Theory of Women's Self-representation, Cornell University, London [Wielka Brytania]. Goetz Bruno (1969), Das ist alles, was ich über Freud zu erzählen habe. Erinnerung an Sigmund Freud, Friedenauer Presse, Berlin [Niemcy].

Grubrich-Simitis Ilse (1997), Freud. Retour aux manuscrits. Faire parler des documents muets, Presses Universitaires de France, Paris [Francja].

Haverty Rugg Linda (1997), Picturing Ourselves. Photography and Autobiography, University of Chicago Press, Chicago [USA].

Jones Ernest (1959), Free Associations. Memories of Psychoanalyst, The Hogarth Press, London [Wielka Brytania].

Jones Ernest (1962), The Life and Work of Sigmund Freud, Hogarth Press, London [Wielka Brytania].

Kirsner Douglas (2007), Saving Psychoanalysts. Ernest Jones and the Isakowers, „Psychoanalysis and History”, nr 9, s. 83-91.

Man Paul de (1986), Autobiografia jako od-twarzanie, przeł. Maria Bożena Fedewicz, „Pamiętnik Literacki”, nr 77 (2), s. 307-318.

May Ulrike (2003), The Early Relationship between Sigmund Freud and Isidor Sadger: A Dream (1897) and A Letter (1902), „Psychoanalysis and History", nr 5 (2), s. 119-145.

Mühlleitner Elke (1992), Biographisches Lexikon der Psychoanalyse.

Die Mitglieder der Psychologischen Mittwoch-Gesellschaft und der Wiener Psychoanalytischen Vereinigung 1902-1938, Diskord, Tübingen [Niemcy].

Mühlleitner Elke, Johannes Reichymayr (1997), Following Freud in Vienna. The Psychological Wednesday Society and the Viennese Psychoanalytical Society 1902-1938, „International Forum of Psychoanalysis", nr 6, s. 73-102. 
Nietzsche Fryderyk (2004), Tako rzecze Zaratustra, przeł. Wacław Berent, Antyk, Kęty.

Nunberg Herman, Federn Ernst, red. (1962), Minutes of the Vienna Psychoanalytic Society, vol. 1, przel. M. Nunberg, International Universities Press, New York [USA].

Nunberg Herman, Federn Ernst, red. (1967), Minutes of the Vienna Psychoanalytic Society, vol. 2, przeł. M. Nunberg, International Universities Press, New York [usA].

Rank Otto (1922), Die Don Juan-Gestalt. Ein Beitrag zum Verständnis der sozialen Funktion der Dichtkunst, „Imago”, nr 8 (2), s. 142-196.

Rank Otto (1927), Don Juan und Leporello, „Almanach der Psychoanalyse”, z. 2, s. 172-182.

Rider Jacques Le (2000), Journaux intimes viennois, Presses Universitaires de France, Paris [Francja].

Roazen Paul (1991), Helene Deutsch. A Psychoanalyst's Life, Transaction Publishers, New Jersey [USA].

Robinson Paul A. (1970), The Freudian Left. Wilhelm Reich, Geza Roheim, Herbert Marcuse, Harper and Row, New York [USA].

Rudnytsky Peter L. (2002), Reading Psychoanalysis. Freud, Rank, Ferenczi, Groddeck, Cornell University Press, London-Ithaca [Wielka Brytania-USA].

Ruitenbeek Hendrik M., red. (1973), Freud as We Knew Him, Wayane State University Press, Detroit [usA].

Sadger Izydor (1877), War Goethe eine pathologische Erscheinung?,

„Deutsche Revue über das gesamte nationale Leben der Gegenwart” nr 24, s. 72-96.

Sadger Izydor (1908), Konrad Ferdinand Meyer. Eine pathographisch-

psychologische Studie, Bergmann, Wiesbaden [Niemcy]

(„Grenzfragen des Nerven- und Seelenlebens”, t. 59).

Sadger Izydor (1910), Heinrich von Kleist. Eine pathographisch-

psychologische Studie, Grenzfragen des Nerven- und Seelenlebens,

Bd. 70, J.F. Bergmann, Wiesbaden [Niemcy].

Sadger Izydor (1912), Von der Pathographie zur Psychographie, „Imago”, nr 1 (2), s. 158-175.

Sadger Izydor (1914), Sexualle Perversionen, „Jarbuch fur psychoanalytische und psychopatologische Forschung", nr 6 (1), S. 296-313.

Sadger Izydor (1920), Friedrich Hebbel. Ein psychoanalytischer Versuch, Schriften zur angewandten Seelenkunde, Bd.18, Deuticke, Wien [Austria]. 
Sadger Izydor (1930), Eltern und Kinder, „Zeitschrift für

psychoanalytische Pädagogik”, nr 4 (8-9), s. 288-291.

Sadger Izydor (2005), Recollecting Freud, red. Alon Dundes, przeł.

Johanna Micaela Jacobsen, University of Wisconsin Press,

Wisconsin-Madison [USA].

Schorske Carl E.(1980), Fin-de-Siècle Vienna. Politics and Culture Knopf,

New York [USA].

Schur Max (1972), Freud. Living and Dying, International Universities

Press, Madison [USA].

Scour Max (1972), Freud. Living and Dying, Hogarth Press, London

[Wielka Brytania].

Stekel Wilhelm (1950), The Autobiography of Wilhelm Stekel. The Life

Story of Pioneer Psychoanalyst, Liveright, New York [USA].

Weiss Eoardo (1970), Sigmund Freud as a Consultant. Recollections

of Pioneer in Psychoanalysis, Intercontinental Medical Book

Corporation, New York [USA].

Wittels Fritz (1924), Sigmund Freud. Der Mann, die Lehre, die Schule,

E.P. Tal, Leipzig-Wien-Zürich [Niemcy-Austria-Szwajcaria].

Wittels Fritz (1931), Freud and His Time, Liveright, New York [USA].

Wittels Fritz (1995), Freud and the Child Women. The Memoirs of Fritz

Wittels, Yale University Press, New Haven [USA].

Agnieszka Więckiewicz

(Auto)analytical case study. Isidor Sadger's recollections of Freud

The article presents an analysis of Freud's early biography written by Isidor Isaak Sadger, one of his earliest students. The author argues that Sigmund Freud. Persönliche Erinnerungen bonds together different literary genres such as biography, autobiography and pathography, thus allowing for studying the impact of life-writing literature on psychoanalysis. The first part of the article is devoted to the relation between introspection, auto-analysis and everyday writing practices of Freud and his students. In the second part, the author presents unknown facts from Sadger's history in the psychoanalytic movement and reads his biography as an example of a heterogeneous literary genre where he becomes a writer-biographer and a doctor-autobiographer simultaneously.

Keywords: psychoanalysis; autobiography; pathography; Isidor Sadger; autoanalysis; Sigmund Freud; antisemitism. 
Agnieszka Więckiewicz - absolwentka kulturoznawstwa w Instytucie Kultury Polskiej na Uniwersytecie Warszawskim oraz filologii polskiej na Uniwersytecie Sorbony; publikowała w „Tekstach Drugich”, „Przeglądzie Humanistycznym”, „Tekstualiach”, „Widoku. Teoriach i Praktykach Kultury Wizualnej”, „Praktyce Teoretycznej”, pismach studenckich i tomach zbiorowych. Członkini Collegium Invisibile oraz zarządu Polskiego Towarzystwa Genderowego im. Marii Skłodowskiej-Curie i Mikołaja Kopernika; laureatka VII edycji konkursu Diamentowy Grant na realizację projektu Między autoanaliza a autobiografią. Codzienne praktyki piśmienne pierwszych uczniów Freuda oraz ich wptyw na ksztaltowanie się teorii psychoanalitycznej; interesuje się teorią i historią psychoanalizy, teorią postkolonialną oraz badaniami nad Zagładą. Dwukrotna stypendystka Ministra Nauki i Szkolnictwa Wyższego za wybitne osiągnięcia naukowe. Adres e-mail: agnieszka.wieckiewicz@ gmail.com. 